\title{
Experimental determination of the time of concentration, Sapucajuba creek small
}

\section{watershed study}

\author{
Determinação experimental do tempo de concentração, estudo da Microbacia do Igarapé
}

Sapucajuba

\section{Determinación experimental del tiempo de concentración, estudio de la cuenca del Igarapé}

Sapucajuba

\begin{abstract}
Time of concentration $\left(t_{c}\right)$ is a parameter that indicates the response time of a river catchment to a rainfall. Frequently, empirical equations are used to determination of $t_{c}$ for the design of the maximum flow. However, the determination of this response time by equations sometimes results in an erroneous application, that is, outside its field of validity. Thus, the present work aimed to determine $t_{c}$ in an experimental and simplified way in the Sapucajuba creek, from measurements in the field, with saline tracer, and to make a comparison with 13 empirical models, which require the morphometric characteristics of the small watershed. It was observed that they underestimated the time of concentration value, in general, by empirical models, overestimating the future project flow. DNOS (sandy-clay condition, intense vegetation, high absorption) was the most indicated model for the estimate of $t_{c}$, that provided the lowest percentage error, $1.92 \%$, compared to $t_{c}$ measured in the field. However, such error exceeded $70.00 \%$ by other models, showing great variability. Therefore, it is strongly recommended the determination of $t_{c}$ in field, that will provide a real result, contributing to the economic dimensioning of hydraulic-hydrological works and projects.
\end{abstract}

Keywords: Time of concentration; Saline tracer; Morphometric characteristics.

\section{Resumo}

O tempo de concentração $\left(\mathrm{t}_{\mathrm{c}}\right.$ ) é um parâmetro que indica o tempo de resposta de uma bacia hidrográfica associado a uma precipitação e em modelos hidrológicos é usado para estimar o pico de cheia. Quase sempre a determinação do $\mathrm{t}_{\mathrm{c}}$ para o dimensionamento da vazão máxima em obras hidráulicas é feita por métodos práticos usando equacionamento empírico. No entanto, a determinação deste tempo de resposta por equações de forma indiscriminada resulta, algumas vezes, numa aplicação errônea, isto é, fora do seu campo de validade. Desta forma, o presente trabalho teve como objetivo determinar o $t_{c}$ de forma experimental e simplificada para a microbacia hidrográfica do Igarapé Sapucajuba, a partir de medições em campo, com auxílio de traçador salino, e fazer uma comparação com 13 modelos empíricos, que necessitam das características morfométricas da microbacia hidrográfica. Na estimativa do $\mathrm{t}_{\mathrm{c}}$ pelos modelos empíricos, de uma forma em geral, observou-se que estes subestimaram o valor do tempo de concentração, superestimando, assim, a futura vazão de projeto, sendo o modelo mais indicado para a estimativa do $t_{c}$, no caso estudado, o do DNOS (condição areno-argiloso, vegetação intensa, elevada absorção) que forneceu o menor erro percentual, 1,92\%, em comparação ao $t_{c}$ medido em campo. No entanto, tal erro ultrapassou $70,00 \%$ por outros modelos, mostrando grande variabilidade. 
Portanto é fortemente recomendada a determinação em campo do $\mathrm{t}_{\mathrm{c}}$ que fornecerá um resultado real, contribuindo para o dimensionamento econômico de obras e projetos hidráulico-hidrológicos.

Palavras-chave: Tempo de concentração; Traçador salino; Características morfométricas.

\section{Resumen}

El tiempo de concentración $\left(t_{c}\right)$ es un parámetro que indica el tiempo de respuesta de una cuenca asociada a una precipitación y en modelos hidrológicos se utiliza para estimar el pico de crecida. La determinación del t $t_{c}$ para el diseño del caudal máximo en obras hidráulicas casi siempre se realiza por métodos prácticos utilizando ecuaciones empíricas. Sin embargo, la determinación de este tiempo de respuesta mediante ecuaciones de forma indiscriminada resulta en ocasiones en una aplicación errónea, es decir, fuera de su campo de validez. Así, el presente trabajo tuvo como objetivo determinar el $t_{c}$ de forma experimental y simplificada para la cuenca del Igarapé Sapucajuba, a partir de mediciones en campo, con la ayuda de trazadores salinos, y realizar una comparación con 13 modelos empíricos, que requieren las características morfométricas de la cuenca. En la estimación del $t_{c}$ por los modelos empíricos, en general, se observó que subestimaron el valor del tiempo de concentración, sobrestimando así el flujo futuro del proyecto, siendo el modelo más adecuado para estimar el $t_{c}$, en el caso estudiado, el de DNOS (condición arenosa-arcillosa, vegetación intensa, alta absorción) que presentó el menor error porcentual, 1,92\%, respecto al $t_{c}$ medido en campo. Sin embargo, este error superó el 70,00\% para otros modelos, mostrando una gran variabilidad. Por ello, se recomienda encarecidamente determinar en el campo el $t_{\mathrm{c}}$ que brindará un resultado real, contribuyendo al dimensionamiento económico de las obras y proyectos hidráulicos e hidrológicos.

Palabras clave: Tiempo de concentración; Trazador salino; Características morfométricas.

\section{Introduction}

Time of concentration $\left(t_{c}\right)$ is one of the main parameters of hydrological characterization of watershed, since it is used in several applications, among which stand out: prevention and minimization of the consequences of natural disasters and point pollution in water resources; definition of the hydrological monitoring interval; urban drainage projects and; elaboration of drainage hydrogram (Silveira, 2005; De Almeida et al., 2013; Mota \& Kobiyama, 2015).

Initially, Mulvany in 1850, in his study, conceptualized the time of concentration as being the time necessary for the rain that falls at the most remote point of the watershed to reach the outfall, or until the entire area of the watershed contributes to the flow in the outfall (Collischonn \& Dornelles, 2015; Oliveira et al., 2017; Lima and Da Paz, 2016; Lousada \& Camacho, 2018; Souza, et al. 2018). Later, the definition and the concept of time of concentration were perfected, according to the point of view considered. Currently, it is concluded that the most remote point is determined hydraulically, and not only by the greatest distance (Mota et al., 2016; Beven, 2020).

According to Silveira (2005); Miguel and Rennó (2020), as the last drop to reach the farthest water body corresponds theoretically to low magnitude flows, the time of concentration, defined as the difference between the end of rainfall and the end of surface runoff, tends to be greater than the "true" time of concentration that is influenced by hydraulic propagation with higher average load. Thus, although time of concentration is widely studied and used, its evaluation is quite complex, due to the numerous factors involved (Sampaio et al., 2016).

Several equations, mostly empirical in nature, are intended to allow the determination of the time of concentration, based on the morphometric characteristics of the watershed that must be previously known to determine this parameter (Silveira, 2005; De Almeida et al., 2013; Mota \& Kobiyama, 2015). These equations are often used indiscriminately, without observing their field of validity (Sampaio et al., 2016).

For engineering projects, losses are related to calculations of maximum design flows, which can be under or overestimated. Project errors can generate consequences such as: increased risks to the health of the population and to the preservation of the environment, increased costs of urban drainage works and increased social inequality (Baptista \& Netto, 2004; Lucas, 2019). Highlight should be given in areas that suffer from urban flooding, such as the urban area of the municipality of Belém/PA, which, especially in the rainy season, cause social and economic losses. An alternative to avoiding errors in time of concentration is to carry out measurements in the field and relatively low cost and practical methodologies may be used. 
As the process of urbanization increasingly occupies the drainage areas, it is essential to collect data that enable studies to predict the occurrence of hydrological events (Silva et al., 2020). However, many of the watershed areas do not have a monitoring focused on environmental and water resources management studies, and it is important to obtain data for these sites (Oliveira et al., 2017). In relation to Brazil, especially the Amazon region, there is a lack of hydrological studies in small watershed (Mota et al., 2016; Oliveira et al., 2017), mainly studies requiring field measurements using high precision equipment. However, the use of simpler and more efficient methodologies, such as methods using saline tracers, would facilitate the development of studies and provide the exact and real value of the time of concentration for a watershed.

The small watershed does not have an universal concepts that classify them as such, and, as the case may be, the researchers determine maximum area limits for them. In the study by Beck et al. (2013), a small watershed was considered to have less than $1 \mathrm{~km}^{2}$ of drainage area. In the national hydrological monitoring network, although recognizing the relevance of small watershed for water resource management, there are few river stations in watersheds with less than $500 \mathrm{~km}^{2}\left(\mathrm{Mota}^{\mathrm{et}}\right.$ al., 2016).

Thus, conducting studies in watersheds is fundamental for the understanding of physical, biological and chemical processes involved in the ecology of watershed located in a given region, because they have similar characteristics. In the direct determination of the time of concentration, from field measurements, tracers may be used which, according to Silva et al. (2009), are any substances, or particles/entities (chemical or biological), that can be used to follow, either punctually or continuously, the behavior of a given system or component, such as water volume, either in an open environment (surface hydrology) or underground environment (porous or cracked environment).

Among the types of tracers are conservatives, who do not change their characteristics when in contact with other substances, and sodium chloride $(\mathrm{NaCl})$, which is easy to acquire, low cost and easy to detect, should be highlighted (can be used an electrical conductivity sensor), are non-toxic, in the concentrations used, and do not present risks of environmental pollution or health (Matos, et al., 2015; Passos et al., 2018; Oliveira et al., 2017).

In engineering, some works, using tracers for parameter determination, can be highlighted, such as the one developed by Borges et al. (2009), where fluorescent tracers (rhodamine WT and sodium fluorescein) were used to determine the experimental residence time (RT) of flooded systems constructed (FSC) from subsurface runoff. In the studies by Passos et al. (2018) tests were carried out with saline tracer $(\mathrm{NaCl})$ for the determination of the hydraulic detention time (HDT) of two shallow polishing ponds for small communities, one without chicanes and the other with two longitudinal chicanes and less depth.

Cuartas et al. (2012), in their work, injected instantly (pulse) a salt solution into the creek, approximately $50 \mathrm{~m}$ upstream of the point where the concentration of the tracer cloud was measured. This methodology was also used in the work of Bortoluzzi and Fernandez (2007), in small water bodies located in the Campus Marechal Cândido Rondon, of the Universidade Estadual do Oeste do Paraná (UNIOESTE), who compared this method, which calls it the Chemical Method of Integration, with other flow measurement methods, such as the volumetric method and the area-speed method. In the work of Carvalho et al. (2014), this methodology was applied in the Rio do Crato, located in the city of Humaitá/Amazonas, having a very satisfactory result compared to the windlass method.

By the way, the objective of this study is to determine the real time of concentration of the Sapucajuba creek, located in the Campus Prof. José da Silveira Netto, of the Federal University of Pará (UFPA-Belém) from the use of a saline tracer (sodium chloride) as well as to evaluate the error between the experimentally measured time of concentration and the time of concentration estimation models in the literature. 


\section{Methodology}

\subsection{Empirical and semi-empirical models for time of concentration determination}

The most commonly used models for the determination of time of concentration are listed in Table 1 (equations 1 to 8). Several studies have already used such models to verify whether they are suitable for use in certain watershed, with distinct characteristics, such as the works of Silveira (2005), Almeida et al. (2013), Sampaio et al. (2016), Ferreira et al. (2017), among others.

Table 1: Summary of the models presented for time of concentration calculation.

\begin{tabular}{|c|c|c|c|}
\hline Model & Equation & $\begin{array}{l}\text { Watershed } \\
\text { type }\end{array}$ & Ordinance \\
\hline Kirpich & $t_{c}=57 \cdot\left(\frac{L^{3}}{H}\right)^{0.385}$ & Rural & 1 \\
\hline Giandotti & $t_{c}=\frac{4 \cdot \sqrt{A}+1.5 \cdot L}{0.8 \cdot \sqrt{H_{m}}}$ & Rural & 2 \\
\hline Dooge & $t_{c}=0.3649 \cdot A^{0.41} \cdot S^{-0.17}$ & Rural & 3 \\
\hline $\begin{array}{l}\text { Corps of } \\
\text { Engineers }\end{array}$ & $t_{c}=0.191 \cdot L^{0.76} \cdot S^{-0.19}$ & Rural & 4 \\
\hline DNOS & $t_{c}=0.419 \cdot k^{-1} \cdot A^{0.3} \cdot L^{0.2} \cdot S^{-0.4}$ & Rural & 5 \\
\hline George Ribeiro & $t_{c}=0.222 \cdot(1.05-0.2 \cdot p)^{-1} \cdot L \cdot S^{-0.04}$ & Rural & 6 \\
\hline Ven te Chow & $t_{c}=0.16 \cdot L^{0.64} \cdot S^{-0.32}$ & Rural & 7 \\
\hline Carter & $t_{c}=0.0977 \cdot L^{0.6} \cdot S^{-0.3}$ & Urban & 8 \\
\hline
\end{tabular}

Source: Authors themselves.

In Table 1, the L for the Ven te Chow, Carter and Corps of Engineers models corresponds to the length of the water course/main channel in kilometers. For the models of Kirpich, DNOS, Giandotti and George Ribeiro, L corresponds to the length of the slope, in kilometers. The definition of $\mathrm{S}$ also varies, being for the models of Ven te Chow, Carter and Corps of Engineers defined as being the mean slope of the watercourse/main channel, in $\mathrm{m} / \mathrm{m}$. For the DNOS and George Ribeiro models, $\mathrm{S}$ is defined as the river slope, in $\mathrm{m} / \mathrm{m}$. The watershed area corresponds to "A", in square kilometers. The slope difference between the furthest point and the watershed reference section corresponds to $\mathrm{H}$ in meters. $\mathrm{Hm}$ is defined as the average elevation from the outfall in meters. The variable "p" corresponds to the area fraction with forest, dimensionless, ranging between 0 and 1. Factor k of the DNOS model was determined according to Silveira (2005) and taking into account the characteristics of the land of the watershed.

Factor k of the DNOS model was determined according to Silveira (2005) and taking into account the characteristics of the land of the watershed. 


\subsection{Field of study}

The area covered by the study comprises the watershed of the Sapucajuba creek, which is located in the neighborhood of Terra Firma, municipality of Belém-PA. The Sapucajuba creek has the drainage in the Guamá river, which, according to the tide (strong influence of tide of the Guamá river and the Guajará bay), reverses the direction of the drainage in part of its extension.

According to Almeida and Penner (2017), the small watershed drains an area of $0.987 \mathrm{~km}^{2}$, holding approximately $63.90 \%$ of green area $\left(0.630 \mathrm{~km}^{2}\right)$ and a runoff coefficient of 0.6. From the spring to the mouth of the Sapucajuba creek, the creek has a length of approximately $1.80 \mathrm{~km}$. In relation to the topography data, the planialtimetric survey was carried out from the source to the mouth of the Sapucajuba creek, on 08/12/2019, using a Total Station model GPT-3207N of the TOPCON brand, resulting in the longitudinal profile present in Figure 1.

Figure 1: Longitudinal profile of the Sapucajuba creek.

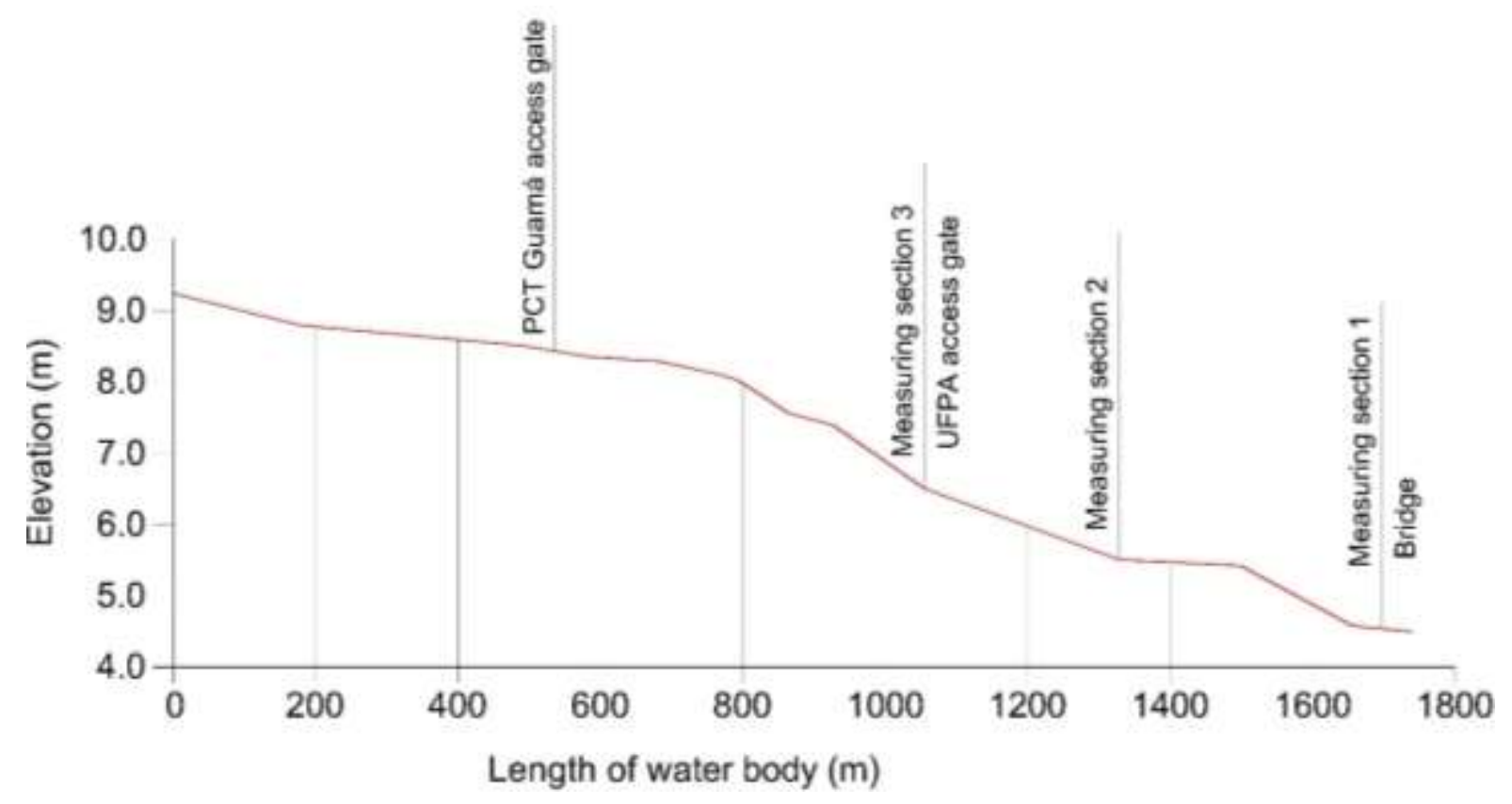

Source: Authors themselves.

\subsection{Flow measurement by salt dissolution method}

The determination of the flow of the Sapucajuba creek was performed using the methodology described in Cuartas et al. (2012), which is based on the measurement of the dispersion of a saline tracer in the water course. The electrical conductivity of the Solution was measured using a 3\% accuracy conductivity probe by Vernier (model: COM-BTA). The distances between the injection points of the saline tracer and the measurement in the concentration cloud, the measurement interval, the total measurement time and the mass of the solute were standardized by initial tests.

Before the saline tracer was injected into the water body, the electrical conductivity of the solutions to be introduced (inside each container) and the water body where the flow was measured. It should be noted that, for the preparation of solutions, water from the water body itself was used.

Simultaneously, the injection of the solution into the river, in the form of a pulse (immediate and punctual release), initiated the recording of the electrical conductivity, finishing the measurement when the measured concentration in the water body returned to its initial concentration (background), or next to it. To determine the flow of the river, we used Equation (9) presented in Cuartas et al. (2012). 


$$
Q=\frac{\left(c_{i}-c_{b}\right) \cdot V_{i}}{\int_{0}^{\infty}\left(c(t)-c_{b}\right) d t}
$$

Where: $\mathrm{Q}$ is the flow of the river, in $\mathrm{m}^{3} \cdot \mathrm{s}^{-1} ; \mathrm{c}_{\mathrm{i}}$ is the concentration of the salt in the solution; $\mathrm{c}_{\mathrm{b}}$ is the concentration of the creek before injecting the solution; $\mathrm{c}_{(\mathrm{t})}$ is the concentration in time $\mathrm{t}$, in seconds and; $\mathrm{V}_{\mathrm{i}}$ is the injected volume of the saline tracer, in $\mathrm{m}^{3}$.

\subsection{Determination of time of concentration using tracer}

The determination of the time of concentration was performed in three parts of the studied water body. For this purpose, a methodology similar to that used for flow measurement was used. According to Azizian (2019), the real time of concentration is determined by considering the travel time of the tracer concentration cloud, from the injection of the saline tracer to the measurement of the electrical conductivity peak (highest value) determined at the measurement point.

\subsection{Test testing campaign}

The GMD (Good Mixing Distance) was determined by means of field experiments, which consisted of collecting samples simultaneously in different verticals in the monitoring sections and comparing the crossing curves of the tracers in each of the verticals. This procedure is recommended by Silva et al. (2017). With the analysis of the results of this procedure it was possible to define the concentration of the tracer solution, the total measurement time and the measurement interval of the electrical conductivity.

In the first test, to prepare the saline solution, we used: $18 \mathrm{~L}$ of water removed from the water body and $500 \mathrm{~g}$ of $\mathrm{NaCl}$. Due to local conditions, the distance between the injection point and the measuring point was $7.5 \mathrm{~m}$. The measurement interval was $8 \mathrm{~s}$ and the total test time was $416 \mathrm{~s}$.

In the second test, to prepare the saline solution, we used: $45 \mathrm{~L}$ of water from the water body and $3 \mathrm{~kg}$ of salt. The distance between the injection point and measurement was 11 meters. The measurement interval was $8 \mathrm{~s}$ and the total test time was $1488 \mathrm{~s}$.

\subsection{Flow and time of concentration test campaigns}

With the defined field conditions, the concentration and flow time determination tests were started. The location of the parts studied is shown in Figure 2. These excerpts were chosen due to the accessibility to the tests and to the greater spatial distribution of the parts studied. 
Figure 2: Field tests sections.

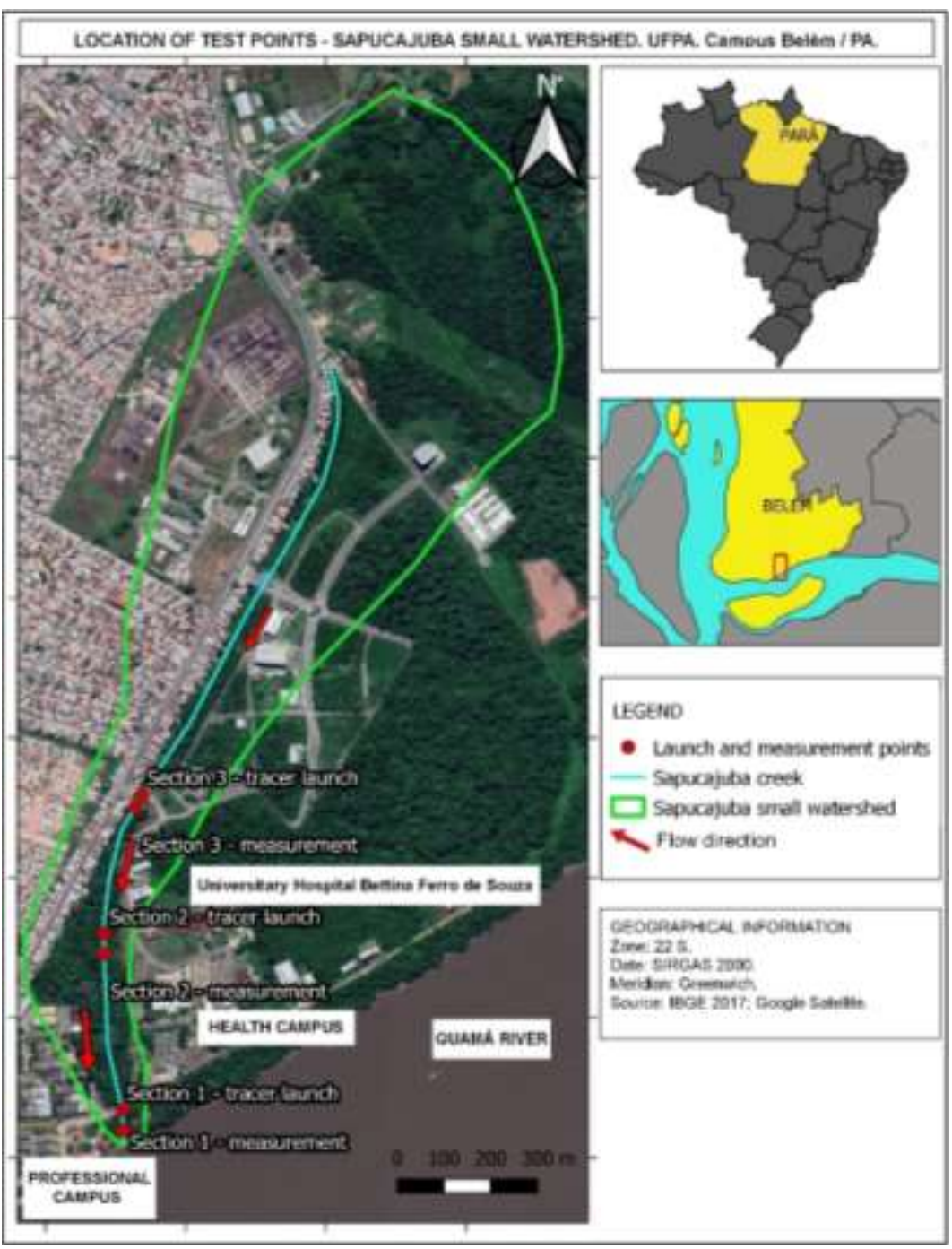

Source: Authors themselves.

The time of concentration in the entire watershed was determined considering the average times found in each stretch.

Comparison with empirical methods with the time of concentration measured in the field, time of concentration estimates were performed from the models listed in Table 1, using the following data: drainage area, stalk length, elevation, slope and mean elevation.

Finally, the results were compared, based on the percentage error calculated by Equation (10) and the most appropriate models were identified for the watersheds that present characteristics similar to the studied hydrographic small watershed, as support for future work.

$$
E \%=\frac{\mid t_{c} \text { medido }-t_{c} \text { calculado } \mid}{t_{c} \text { medido }} \cdot 100
$$

Where: $\mathrm{E} \%$ is the percent error; measured $\mathrm{t}_{\mathrm{c}}$ is the measured time of concentration; calculated $\mathrm{t}_{\mathrm{c}}$ is the calculated time of concentration. 


\section{Results and Discussion}

\subsection{Test Trials}

The tests showed that it is essential to work with more than 40 liters of saline solution and at least $3 \mathrm{~kg}$ of salt. Smaller volumes of water with a smaller salt mass provided curves that were difficult to detect. The optimal lead time ranged from 4 to 20 minutes, depending on the stretch considered, ensuring the marking of every tracer cloud on any stretch, and the interval between measurements of 1 to 20 seconds.

It should be noted that this stage was of paramount importance to be able to have sensitivity in relation to the field analysis, and should pay attention to the necessary adjustments, thus avoiding unreal results, as recommended by Silva, et al. (2017).

\subsection{Determination of flow rate and time of concentration}

Table 2 shows the conditions for the tests in each section, as well as the results obtained, flow rate and time of concentration. Figure 3 shows the graph of dimensionless electrical conductivity (measured value - lowest value / highest value - lowest value) as a function of dimensionless time (measured time/final time), obtained from field tests for Sections 1, 2 and 3.

Table 2: Test conditions and results for all sections.

\begin{tabular}{|c|c|c|c|c|c|c|}
\hline \multirow{2}{*}{ Alternating } & \multicolumn{2}{|c|}{ Stretch 1} & \multicolumn{2}{|c|}{ Stretch 2} & \multicolumn{2}{|c|}{ Stretch 3} \\
\hline & E1 & E2 & E1 & E2 & E1 & E2 \\
\hline Measurement range (s) & 1 & 3 & 4 & 4 & 20 & 20 \\
\hline Total test time (s) & 240 & 240 & 480 & 480 & 1200 & 900 \\
\hline Mass of $\mathrm{NaCl}(\mathrm{g})$ & $3 \mathrm{k}$ & $3 \mathrm{k}$ & $3 \mathrm{k}$ & $3 \mathrm{k}$ & $3 \mathrm{k}$ & $3 \mathrm{k}$ \\
\hline $\begin{array}{l}\text { Electrical conductivity of saline solution } \\
(\mu \mathrm{S} / \mathrm{cm})\end{array}$ & 4096 & 4096 & 4038 & 4040 & 3975 & 4001 \\
\hline $\mathrm{c}_{\mathrm{i}}$ - Concentration of saline solution $(\mathrm{mg} / \mathrm{L})$ & 2,048 & 2,048 & 2,019 & 2,020 & $1,987.5$ & $2,000.5$ \\
\hline $\begin{array}{l}\text { Initial electrical conductivity in the } \\
\text { watercourse }(\mu \mathrm{S} / \mathrm{cm})\end{array}$ & 196.51 & 196.51 & 296.26 & 303.44 & 264.18 & 273.71 \\
\hline $\begin{array}{l}c_{b}-\text { Initial saline concentration in the } \\
\text { watercourse }(\mathrm{mg} / \mathrm{L})\end{array}$ & 98.25 & 98.25 & 148.13 & 151.72 & 132.09 & 136.85 \\
\hline $\mathrm{V}_{\mathrm{i}}$ - Volume of saline tracer $(\mathrm{L})$ & 54 & 54 & 49,5 & 48 & 48 & 48 \\
\hline Q - Calculated flow rate $(\mathrm{L} / \mathrm{s})$ & 4.67 & 4.07 & 1.64 & 1.57 & 2.08 & 2.46 \\
\hline $\mathrm{t}_{\mathrm{c}}-$ time to peak $(\mathrm{min})$ & 1.02 & 1.30 & 3.27 & 3.47 & 4.50 & 5.00 \\
\hline
\end{tabular}


Figure 3: Electrical conductivity as a function of time for Section 1, 2 and 3.

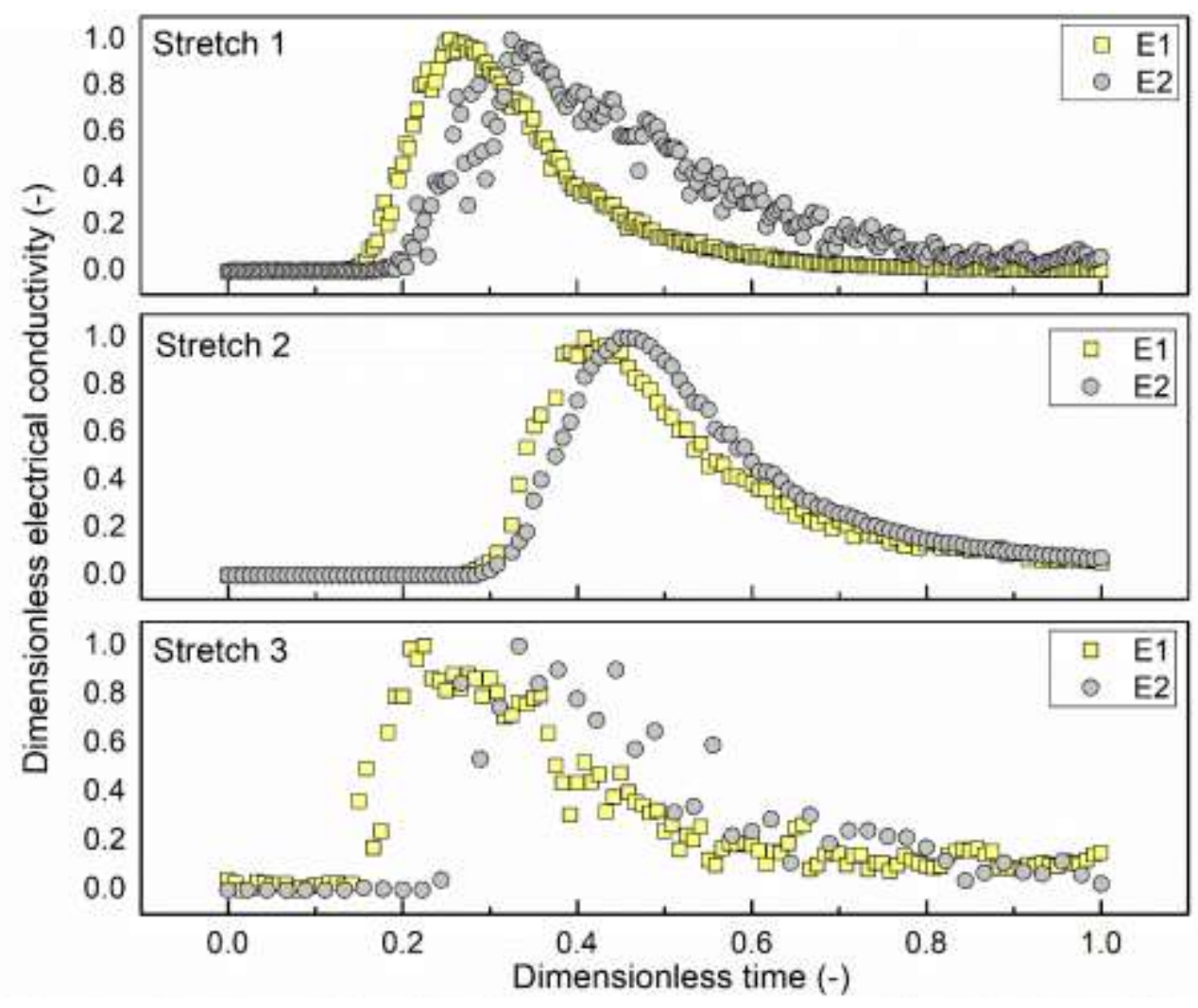

Source: Authors themselves.

Analyzing the arrival curves of Figure 3, it is noted that in all the tests the electrical conductivity left the initial condition, reached a peak and returned to the initial condition or very close to it, sufficient to determine the flow rate and the respective time of concentration per considered stretch. In the case of Experiment 1, there is a lag between Trials 1 and 2, a difference of 9 seconds, and there are small oscillations in the values, probably caused by the non-uniform release of the tracer. For Section 2 , it should be noted that the plotter's arrival curves, in both tests, present a minimum difference, and there are reduced oscillations when compared to the other tests. Finally, for Stretch 3, the finish curves of the tracer differed in Trials 1 and 2, with a difference of 25 seconds in the arrival time between the two. A greater oscillation between the measurements was also evident compared to the other tests.

\subsection{Time of concentration of the entire watershed}

The time of concentration and the displacement velocity are listed in Table 3. Time of concentration ranged between 1.02 and 5.00 min depending on the section considered. The lowest times are observed close to the outfall, which consequently are associated with higher flow velocity. 
Research, Society and Development, v. 10, n. 6, e35210612757, 2021

(CC BY 4.0) | ISSN 2525-3409 | DOI: http://dx.doi.org/10.33448/rsd-v10i6.12757

Table 3: Time of concentration and flow velocity for the small watershed.

\begin{tabular}{|c|c|c|c|c|}
\hline Stretch & Test & Distance (m) launch / measurement & $t_{c}(\min )$ & Velocity $\left(\mathbf{m}^{\prime} \mathbf{m i n}^{-1}\right)$ \\
\hline \multirow{2}{*}{1} & 1 & 25.0 & 1.02 & 24.5 \\
\hline & 2 & 25.0 & 1.30 & 19.2 \\
\hline \multirow{2}{*}{2} & 1 & 30.1 & 3.27 & 9.2 \\
\hline & 2 & 30.1 & 3.47 & 8.7 \\
\hline \multirow{2}{*}{3} & 1 & 19.7 & 4.50 & 4.4 \\
\hline & 2 & 19.7 & 5.00 & 3.9 \\
\hline \multicolumn{2}{|c|}{ Whole watershed } & 1778.5 & 152.3 & 11.7 \\
\hline
\end{tabular}

Source: Authors themselves.

Continue explanation about the flow velocities, which varied between 3.9 and $24.5 \mathrm{~m} \cdot \mathrm{min}^{-1}$, this variation is due to the flow section, since the longitudinal profile, Figure 1, does not indicate significant changes in the slope between the segments considered.

\subsection{Estimated time of concentration}

Considering the methods described in Table 1, the time of concentration was calculated using the morphometric characteristics of the small watershed according to the results of Table 4 . The model that presented the highest $t_{c}$ estimation value was Giandotti's model (207.79 minutes). The lowest values found were obtained by the models of Carter and George Ribeiro (42.99 and 42.86 minutes, respectively). Note that the values of $t_{c}$ obtained for different values of $k$, also differ, being possible to observe that the type of roughness of the land influences directly the value of $t_{c}$, being evident that the more impermeable the area of the watershed, less is the time of concentration. Considering the slope of the river as being 0 to $3 \%$ and having the same, characteristics of urban and rural watershed, we used the arithmetic mean of the maximum speed limits in runoff in pastures and pavements $\left(1.7 \mathrm{~m} \cdot \mathrm{s}^{-1}\right)$. In this way, all calculated values, using the models, are below the maximum limit. 
Table 4: Verification of average flow rates in the creek.

\begin{tabular}{|c|c|c|}
\hline Model & $t_{c}(\min )$ & $\begin{array}{c}\text { Average } \\
\text { velocity }\left(\mathrm{m} \cdot \mathbf{s}^{-1}\right)\end{array}$ \\
\hline Kirpich & 71.16 & 0.55 \\
\hline Giandotti & 207.79 & 0.19 \\
\hline Dooge & 58.08 & 0.68 \\
\hline Corps of Engineers & 50.38 & 0.59 \\
\hline George Ribeiro & 42.86 & 0.92 \\
\hline Ven te Chow & 80.41 & 0.37 \\
\hline Carter & 42.99 & 0.69 \\
\hline Clayey sand, intense vegetation, high absorption & 149.46 & 0.26 \\
\hline Common, vegetation covered, appreciable absorption & 99.64 & 0.39 \\
\hline Clayey, overgrown, medium absorption & 74.73 & 0.53 \\
\hline Medium vegetation, little absorption & 66.43 & 0.59 \\
\hline In rock, vegetation sparse, low absorption & 59.73 & 0.66 \\
\hline Rocky, vegetation thin, reduced absorption & 54.35 & 0.72 \\
\hline
\end{tabular}

Source: Authors themselves.

The variety of results obtained for the time of concentration shows that the models were developed in specific watersheds, with different characteristics and situations among themselves, some of which differ from the characteristics of the small watershed studied, shown that no field measurement can be a risky choice.

\subsection{Comparative analysis of $t_{c}$ calculated with $t_{c}$ measured in field (real)}

The $t_{c}$ value estimated by the Kirpich model (the most commonly used) presented a lower value than the $t_{c}$ measured in the field, with an error of 50\%. This can be explained by the fact that the studied small watershed exceeds the limit area of application of the model $\left(0.500 \mathrm{~km}^{2}\right)$. Silveira (2005) comments that when its application is extrapolated to larger watersheds, it is expected to obtain lower time of concentration than the real ones. The value of $t_{c}$ estimated by Giandotti's model is much higher than the value of $t_{c}$ measured in the field, thus overestimating the calculation result. This verification was also made in the work of Silveira (2005), who, because the model uses the area of the watershed as an explanatory variable, exhibits the tendency to overestimate the time of concentration, regardless of the amplitude of the accepted areas. Another study in which the overestimation of this model was noted was that of Sampaio et al. (2016). He estimated $t_{c}$ for 28 watersheds in Ceará state, 
using 11 methods of estimating $t_{c}$. The value closest to that of $t_{c}$ measured was that estimated by the DNOS model (in sandyclay terrain, intense vegetation, high absorption), $149.46 \mathrm{~min}$.

The comparison of the results of the $t_{c}$ estimate with the results measured in the field, based on the percentage error calculated by Equation (10), is shown in Table 5.

Table 5: Values of percentage errors of each $t_{c}$ estimate model.

\begin{tabular}{|c|c|c|}
\hline \multirow{3}{*}{ Model } & Percent error $(\mathrm{E} \%)$ & \multirow{3}{*}{ Rank } \\
\hline & & \\
\hline & $t_{c}$ for the whole watershed & \\
\hline Kirpich & $53.30 \%$ & $6^{\circ}$ \\
\hline Giandotti & $36.36 \%$ & $3^{\circ}$ \\
\hline Dooge & $61.89 \%$ & $9^{\circ}$ \\
\hline Corps of Engineers & $66.94 \%$ & $11^{\circ}$ \\
\hline George Ribeiro & $71.88 \%$ & $13^{\circ}$ \\
\hline Ven te Chow & $47.23 \%$ & $4^{\circ}$ \\
\hline Carter & $71.79 \%$ & $12^{\circ}$ \\
\hline Clayey sand, intense vegetation, high absorption & $1.92 \%$ & $1^{\circ}$ \\
\hline Common, vegetation covered, appreciable absorption & $34.61 \%$ & $2^{\circ}$ \\
\hline Clayey, overgrown, medium absorption & $50.96 \%$ & $5^{\circ}$ \\
\hline Medium vegetation, little absorption & $56.41 \%$ & $7^{\circ}$ \\
\hline In rock, vegetation sparse, low absorption & $60.77 \%$ & $8^{\circ}$ \\
\hline Rocky, vegetation thin, reduced absorption & $64.34 \%$ & $10^{\circ}$ \\
\hline
\end{tabular}

Source: Authors themselves.

Estimation errors of $t_{c}$ varied between 1.92 (DNOS model for intense vegetation) and 71.88\% (George Ribeiro). This variation is due to the great variety of watersheds used for the elaboration of each model.

Also, in Table 5 are presented the most appropriate models, that is, closer to the values measured in the field, for the small watershed, in order of placement. The three most suitable models for the small watershed studied were: DNOS (intense vegetation, high absorption), DNOS (vegetation cover, appreciable absorption) and Giandotti, from the 1st to the 3rd place, respectively. Better results were also found for the DNOS model in the study by Silveira (2005).

The model that presented the worst result was George Ribeiro (percentage error of 71.88\%), staying in the 13th position, and he exhibits the tendency to overestimate the time of concentration. 
The performance of the Dooge model, based on data from ten rural watersheds in Ireland, with areas between 140 and $930 \mathrm{~km}^{2}$, should better reflect the time of concentration in watersheds where channel flow predominates (Collischonn \& Dornelles, 2015; Silveira, 2005). Therefore, as the watershed of the Sapucajuba creek has a low drainage density and little branching, it is expected that the predominant runoff is over the soil, a fact that may have affected the performance of the Dooge equation, underestimating the time of concentration.

Carter's model, even though it was produced for urban watershed, was in the 10th position, underestimating the time of concentration of the small watershed.

This justification can be given by the preservation of green areas, which, according to Almeida and Penner (2017), the watershed holds approximately $63.9 \%\left(630,389 \mathrm{~m}^{2}\right)$. In general, it was found that the models underestimated the time of concentration value, which consequently overestimated the flow of the water body when this is the objective. This finding is favorable to the safety in the elaboration of urban drainage projects. However, care should be taken that the estimate does not generate economic viability for the execution of the works.

\section{Final Considerations}

This work determined the time of concentration in the watershed of the Sapucajuba creek using saline tracer. Additionally, the measured time of concentration was compared with estimation models present in the literature. The main conclusions are:

- The determination of time of concentration using saline tracers emerges as a viable alternative, given the variability of time of concentration estimated by empirical and semi-empirical models.

- In general, empirical and semi-empirical models underestimated the value of experimentally measured time of concentration. This situation occurs because the models have been developed under different conditions than those of the small watershed used in this study.

As recommendations for better implementation of future field work it is suggested:

- $\quad$ For the same test, perform measurements on at least two separate sections of the watercourse for comparison of results;

- Continuous launch of tracer, avoiding any uncertainties of the instantaneous point launch, with the participation of several auxiliaries in the field, as was the case of the present work, where it was necessary the presence of three operators doing launching.

\section{Acknowledgments}

In memory of Hélio da Silva Almeida, who had died in 03/13/2021.

\section{References}

Azizian, A. (2019). Comparison of salt experiments and empirical time of concentration equations. Proceedings of the Institution of Civil Engineers - Water Management 172(3): 109-122. https://doi.org/10.1680/jwama.17.00048.

Almeida, I. K. De., Anache, J. A. A., Almeida, V. R., \& Sobrinho, T. A. (2013). Estimativa de tempo de concentração em bacia hidrográfica. In: Simpósio Brasileiro de Recursos Hídricos, 20., Anais [...]. Rio Grande do Sul.

Almeida, I. R., \& Penner, G. C. (2017). Caracterização física da bacia do Igarapé Sapucajuba (Belém-PA). In: Congresso Brasileiro de Engenharia Sanitária e Ambiental, 29. São Paulo, 2017, Anais [...]. São Paulo: ABES: AESABESP.

Baptista, L. M. A. C., \& Netto, O. M. C. (2004). Análise multicritério para a avaliação de sistemas de drenagem urbana proposição de indicadores e de sistemática de estudo. Revista Brasileira de Recursos Hídricos, 9(4), 5-19, Out/Dez. https://doi.org/10.21168/rbrh.v9n4.p5-19. 
Beck, H. E., Bruijnzeel, L. A., Van Dijk, A. I. J. M., Mcvicar, T. R., Scatena, F. N., \& Schellekens, J. (2013). The impact of forest regeneration on streamflow In: 12 mesoscale humid tropical catchments. Hydrology and Earth System Sciences, 17(7), 2613-2635. https://doi.org/10.5194/hess-17-2613-2013, 2013.

Beven, K. J. (2020). A history of the concept of time of concentration. Hydrology and Earth System Sciences, 24, 2655-2670, 2020. https://doi.org/10.5194/hess24-2655-2020.

Borges, A. C., Matos, A. T., Calijuri, M. D. C., Oliveira, G. H. H., \& Roldão, J. S. (2009). Uso de traçadores para avaliação da hidrodinâmica de sistemas alagados construídos operando sob condições climáticas tropicais. Engenharia Agrícola, 29(2), 301-310. https://doi.org/10.1590/S0100-69162009000200013.

Bortoluzzi, L. N., \& Fernandez, O. V. Q. (2008) Medição de vazão líquida em pequenos cursos d’água de Marechal Cândido Rondon (PR). Geografia Ensino \& Pesquisa, $\quad$ Santa Maria $\quad$ (PR), $\quad$ v. $4265-4275$. https://www.researchgate.net/publication/236625197_MEDICAO_DA_VAZAO_LIQUIDA_EM_PEQUENOS_CURSOS_D'AGUA_DE_MARECHAL_CA NDIDO_RONDON_PR.

Carvalho, R. R. De., Tartari, R., Radmann, V., \& Pagani, C. H. (2014). Monitoramento da vazão em rios da região sul do Amazonas. Revista EDUCAmazônia, Manaus, ano 7, 12(1), jun/jul., 8-27. https://dialnet.unirioja.es/descarga/articulo/4730897.pdf.

Collischonn, W., \& Dornelles, F. (2015). Hidrologia: para engenharia e ciências ambientais: Associação Brasileira de Recursos Hídricos (ABRH), Coleção ABRH; 12, 336p. ISBN: 978-85-8868-634-2.

Cuartas, L. A., Tomasella, J., Nobre, A. D., Nobre, C. A., Hodnett, M. G., Waterloo, M. J., De Oliveira, S. M., Von Randow, R. De C., Trancoso, R., \& Ferreira, M. (2012). Distributed hydrological modeling of a micro-scale rainforest watershed in Amazonia: model evaluation and advances in calibration using the new HAND terrain model. Journal of Hydrology, v. 462-463, 15-27. https://doi.org/10.1016/j.jhydrol.2011.12.047.

Lima, D. M. \& Da Paz, A. R. (2016). Estudo do efeito da caracterização da rede de drenagem na determinação do tempo de concentração via geoprocessamento. VII Congresso Brasileiro de Gestão Ambiental. Paraíba: IBEAS - Instituto Brasileiro de Estudos Ambientais. https://www.ibeas.org.br/congresso/Trabalhos2016/VIII-030.pdf.

Lucas, B. T. Proposta de metodologia para cálculo da microdrenagem urbana a partir de análise discretizada do escoamento superficial da água de chuva. (2019). (Dissertação de Mestrado). Programa de Mestrado Profissional em Inovação Tecnológica, Universidade Federal do Triângulo Mineiro - UFTM, Uberaba, MG, Brasil, 86p. http://bdtd.uftm.edu.br/handle/tede/962.

Matos, M. P., Sperling, M. V., Matos, A. T., \& Passos, R. G. (2015). Uso de traçador salino para avaliação da colmatação e das condições hidrodinâmicas em sistemas alagados construídos de escoamento horizontal subsuperficial. Engenharia Agrícola, Jaboticabal, 35(6), 1137-1148. https://doi.org/10.1590/1809-4430Eng.Agric.v35n6p1137-1148/2015.

Miguel, B. H., \& Rennó, C. D. Uso de Dados de Radar Meteorológico em Modelo Hidrológico SCS-CN para a Estimativa de Escoamento Superficial. Revista Brasileira de Cartografia, 72(3), 501-516, 22 set. 2020. https://doi.org/10.14393/rbcv72n3-53684.

Mota, A. A., Grison, F., Giglio, J. N., \& Kobiyama, M. (2016). Instalação de uma pequena bacia experimental florestal: estudo de caso da bacia do Rio Araponga. Revista Engenharia Sanitária e Ambiental, 22(1), 73-80. https://doi.org/10.1590/s1413-41522016154610.

Mota, A. A., \& Kobiyama, M. (2015). Reconsiderações sobre a Fórmula de Kirpich para o cálculo de tempo de concentração. Revista Brasileira de Recursos Hídricos, 20(1), 55-59. https://doi.org/10.21168/rbrh.v20n1.p55-59.

Passos, R. G., Dias, D. F. C., Matos, M. P., \& Von Sperling, M. (2018). Sodium chloride as a tracer for hydrodynamic characterization of a shallow maturation pond. Water Practice and Technology, 13, 30-38. https://doi.org/10.2166/wpt.2018.009.

Sampaio, A. S., Sá, P. E. F., Batista, T. L., \& Studart, T. M. C. (2016). Análise do tempo de concentração em função das características fisiográficas em bacias rurais. In: Simpósio de Recursos Hídricos do Nordeste, 13., Aracaju. Anais [...]. Aracaju: ABRHidro. https://abrh.s3.sa-east1.amazonaws.com/Sumarios/81/51b628c0f984da85b0201d42c0cdd10f_2ff3473dd68d07c62117d3505fadc85a.pdf.

Silva, L. L., Donnici, C. L., Ayala, J. D., Freitas, C. H., Moreira, R. M., \& Pinto, M. F. (2009). Traçadores: o uso de agentes químicos para estudos hidrológicos, ambientais, petroquímicos e biológicos. Química Nova, 32(6), 1576-1585. http://dx.doi.org/10.1590/S0100-40422009000600042.

Silva, P. V. R. M. Da., Pecly, J. O. G., \& Azevedo, J. P. S. (2017). Uso de traçadores fluorescentes para determinar características de transporte e dispersão no Rio Piabanha (RJ) para a modelagem quali-quantitativa pelo HEC-RAS. Revista Engenharia Sanitária e Ambiental, 22(3), 463-472. http://dx.doi.org/10.1590/s1413-41522017150187.

Silva, J. J. R., de Assis Oliveira, G., Vieira, E. M., \& Freitas, A. C. V. (2020). Influência da expansão urbana aliada às características morfométricas nas ocorrências de inundações: estudo de caso no município de João Monlevade-MG. Research, Society and Development, 9(2), 1-26. http://dx.doi.org/10.33448/rsdv9i2.2101.

Silveira, A. L. L. (2005). Desempenho de fórmulas de tempo de concentração em bacias urbanas e rurais. Revista Brasileira de Recursos Hídricos, 10(1), 5-23. https://doi.org/10.21168/rbrh.v10n1.p5-29.

Souza, J. C., Reis, J. A. T. Dos., \& Mendonça, A. S. F. (2018). Importance of adequate appropriation of physiographic information for concentration times determination. Revista Ambiente \& Água, 13(4), 1-13. https://doi.org/10.4136/ambi-agua.2184. 